\title{
Industrial Assessment of the Carbonate Rocks of the Pila Spi Formation at Haibat Sultan Mountain, Iraqi Kurdistan Region
}

\author{
Varoujan K. Sissakian ${ }^{1}$, Mohammed J. Hamawandy ${ }^{2}$ and Rahel K. Ibrahim² \\ ${ }^{1}$ Department of Natural Resources Engineering and Management, University of Kurdistan Hewler, \\ Erbil, Kurdistan Region - F.R. Iraq \\ ${ }^{2}$ Department of Civil Engineering, Faculty of Engineering, Koya University, \\ Koya KOY45, Kurdistan Region - F.R. Iraq
}

\begin{abstract}
The Pila Spi Formation is one of the prominent formations forming continuous ridges in Kurdistan Region. The thickness of the formation ranges from 15 to $110 \mathrm{~m}$, consisting of well-bedded limestone, dolomite, dolomitic limestone, and very rare marl beds. The study area is located about $15 \mathrm{~km}$ east of Koya town, next to the abandoned tunnel through a deeply cut valley which has exposed $50 \mathrm{~m}$ of the formation. However, the uppermost part of the exposed section may belong to one of the Oligocene formations of Kirkuk Group. The study area was selected within the Pila Spi Formation because the rocks of the same formation and along the same ridge, about $45 \mathrm{~km}$ west of the study area showed encouraging results for cement industry. The average $\mathrm{CaO}$ is about $51 \%$, whereas the average $\mathrm{MgO}$ is $\mathbf{1 . 8 \%}$. Therefore, eight samples were collected at constant thickness from the exposed section. The samples were subjected to X-ray fluorescence (XRF) test to indicate the main oxides in the sampled section. The acquired results from the XRF tests showed that the chemical composition of the exposed rocks within the Pila Spi Formation is suitable for cement industry, also for paper and paint but needs some treatment. Accordingly, another eight samples were collected from the same section to increase the density of sampling, totaling to 16 samples.
\end{abstract}

Index Terms-Cement and paper industries, Industrial assessment, Pila Spi Formation, Quarrying conditions.

\section{INTRODUCTION}

The Pila Spi Formation (Upper Eocene) forms a long continuous cliff in the Iraqi Kurdistan Region. The formation consists of carbonate rocks; limestone and dolomite (dolostone) with different proportions (Sissakian and Saeed, 2012). Due to extensive facies changes, the percentage of limestone to dolostone is not constant, and it is almost

\footnotetext{
ARO-The Scientific Journal of Koya University Vol. VIII, No.1 (2020), Article ID: ARO.10546, 7 pages DOI: $10.14500 /$ aro. 10546

Received 15 July 2019; Accepted: 30 January 2020

Regular research paper: Published 15 March 2020

Corresponding author's, e-mail: f.khajeek@ukh.edu.krd

Copyright (C) 2020 Varoujan K. Sissakian, Mohammed J. Hamawandy, Rahel K. Ibrahim. This is an open access article distributed under the Creative Commons Attribution License.
}

impossible to indicate a constant ratio for large areas. Moreover, locally, the formation is overlain by one or more of Oligocene rocks of Kirkuk Group. It is worth mentioning that in the majority of the present geological maps, the Oligocene rocks are not presented in those maps. This is because majority of the areas where the Pila Spi Formation is exposed are mapped using aerial photographs in which it is not possible to distinguish the Pila Spi Formation from those of Oligocene age.

\section{A. Aim}

The aim of the current work is to conduct an industrial assessment of the carbonate rocks of the Pila Spi Formation at Haibat Sultan Mountain. The assessment was done by indicating the chemical composition of the rocks acquired from the X-ray fluorescence (XRF) test to calculate the weighted average of the oxides and accordingly compare them with the Iraqi and international standards for different industrial uses.

\section{B. Location}

The study area is located in Haibat Sultan Mountain located approximately $80 \mathrm{~km}$ northeast of Erbil city, between Koisanjak and Dokan towns along the main road (Fig. 1). The sampled section is marked by the following coordinates

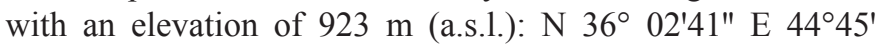
$52^{\prime \prime}$ and $\mathrm{N} 36^{\circ} 02^{\prime} 41^{\prime \prime} \mathrm{E} 44^{\circ} 45^{\prime} 050^{\prime \prime}$ with an elevation of $881 \mathrm{~m}$ (a.s.l.).

\section{Previous Works}

Limestone is used in Iraqi Kurdistan Region mainly for cement production. In Iraqi Kurdistan Region, six cement plants have been constructed. Five of them are located in Sulaymaniyah Governorate, whereas only one is located in Erbil Governorate; moreover, three cement plants have been licensed but not constructed yet. Therefore, building a cement plant in Erbil Governorate to cover the requirements of the construction industry is very significant and also in the Duhok Governorate where no any cement plant exists. To locate a cement plant, relevant reserves of limestone should 


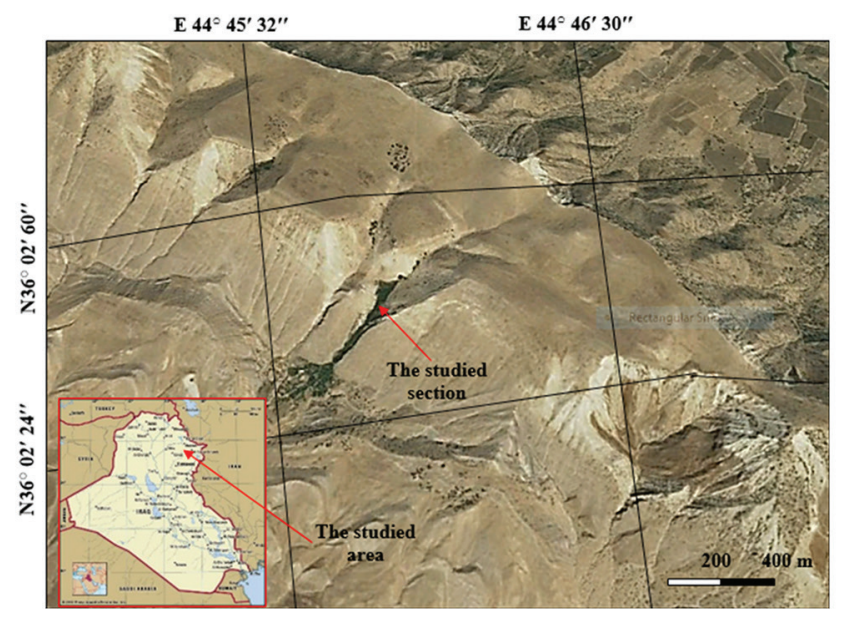

Fig. 1. Satellite image of the study area.

be available with other quarrying conditions besides the presence of clay which is the second main raw material in cement production.

The cement industry in Iraq was very significant subject; therefore, the Iraq Geological Survey (Baghdad) was conducting studies to evaluate the exposed limestone beds everywhere in Iraq since early seventies from the past century. Those studies which dealt with the evaluation of the exposed limestone beds in the Kurdistan Region are briefed hereinafter.

Jaber and Al-Ubaide (1973) evaluated the exposed limestone beds in Kani China area. Al-Rufaie (1976), AlRufaie and Muhamad (1976), Al-Murib (1980), and Hafidh et al. (2011) studied and evaluated the exposed limestone beds in the Anah Formation in Qara Chaugh Mountain. They all reported about excellent quality and quantity of limestone for cement industry. Mansour (1976) evaluated the exposed limestone beds in Kirkuk, Erbil, and Sulaymaniya Governorates and concluded about excellent qualities and quantities of limestone which are suitable for cement industry. Mansour (1977) evaluated the exposed limestone beds for the sake of Al-Tamim (Laylan) cement plant and concluded that the nearest exposed suitable rocks for cement industry are in Qara Chaugh and Bazian. Etabi and Ahmed (1979) studied and evaluated the exposed rocks in Tasluja vicinity for the use of Tasluja cement plant and concluded excellent quality and quantity of limestone beds for cement industry. Mansour and Petranek (1980) reported about the occurrences of limestone suitable for cement industry in the whole Iraqi territory. They concluded that the exposed rocks in Bazian and Qara Chaugh vicinities are the only suitable limestone beds for cement industry in the whole Kurdistan Region. Hafidh and Khlaif (2007) evaluated the reserve estimation in category $\mathrm{C} 1$ for the limestone of the Sinjar Formation in Bazian vicinity. Hafidh and Abdul Hassan (2008) evaluated the exposed limestone in C1 category in Sartak Bamu vicinity south of Derbendikhan on the behalf of Meran Company. Hafidh et al. (2008a) studied and evaluated the exposed limestone beds in Sartak Bamu and Kani Gal vicinities, south of Derbendikhan. Hafidh et al. (2008b) studied and evaluated the exposed limestone beds in Agh Jallar vicinity on the behalf of Mawlawi Company and reported about excellent quality and quantity of limestone which is suitable for cement industry. Hafidh et al. (2008c) studied and evaluated the exposed limestone beds west of Sulaymaniyah on the behalf of Washa Company. This deposit was later on studied and Gasin cement plant was constructed. Sissakian et al. (2019) evaluated the carbonate rocks of the Pila Spi Formation in the southwestern limb of Permam anticline and reported about excellent quality and quantity of limestone.

\section{Geological Setting}

The study area is located within the southwestern limb of Khalikan anticline, northeast of Erbil city, and east of Koya town along the main persistent ridge which forms the contact between the Low Folded Zone (in the south) and the High Folded Zone (in the north). The main geological aspects are briefly described emphasizing the significant features, which have a direct and/or indirect effect on the current study.

\section{A. Geomorphology}

The study area is located; physiographically within the High Mountainous Province (Sissakian and Fouad, 2012). The main geomorphological units are as follows:

- Structural geological units: Among them are the anticlinal ridges, which extend along the anticline. They are developed within the Pila Spi Formation.

- Structural-denudational units: Among them are the flatirons (Fig. 2), which are well developed within the Pila Spi Formation. Other units are the erosional scarps which are developed within the Pila Spi Formation.

\section{B. Tectonic and Structural Geology}

The study area is located along the contact between the Low Folded Zone (in the south) and the High Folded Zone (in the north). Both zones are located in the Outer Platform of the Arabian Plate. They also belong to the Zagros ThrustFold Belt (Fouad, 2012). The study area occurs within the southwestern limb of Khalikan anticline which is very broad fold giving to the southwestern limb of the anticline a monoclonal form.

\section{Stratigraphy}

The Pila Spi Formation is widely exposed in the study area. It forms a continuous cliff in the study area forming large flatirons (Figs. 1 and 2). The upper contact of the formation with the overlying Fatha Formation is unconformable. The lithological composition of the formation is almost constant throughout the study area and consists of carbonate rocks. The carbonate rocks are mainly limestone with a presence of dolomitic limestone and dolomite. The thickness of the formation is highly variable, in the study area, it is about $85 \mathrm{~m}$ (Sissakian and Fouad, 2014, and Sissakian and Al-Jibury, 2014). However, 
in the study area, the Pila Spi Formation is most probably overlain by Oligocene rocks; one of the formations of the Kirkuk Group (Fig. 3).

\section{Materials AND MethodS}

The following materials were used to perform the current study.

- Geological map at a scale of 1:250,000.

- Satellite images of high resolution.

- Relevant literature, including published papers, books, concerning the usage of the carbonate rocks in industry.

- Samples were collected from the outcrops of the Pila Spi Formation, along a deep cut valley within the main ridge of the formation (Fig. 3).

To perform industrial assessments for the carbonates of the Pila Spi Formation at Haibat Sultan Mountain, eight samples were collected in the first stage and other eight samples in the second stage totaling to 16 rock samples. Samples were prepared and subjected to XRF analyses. After receiving the acquired results from the XRF test, which was carried out in the laboratories of the University of Kurdistan Hewler, the weighted averages for each oxide at each sample were calculated and compared with different standards (Table I) to

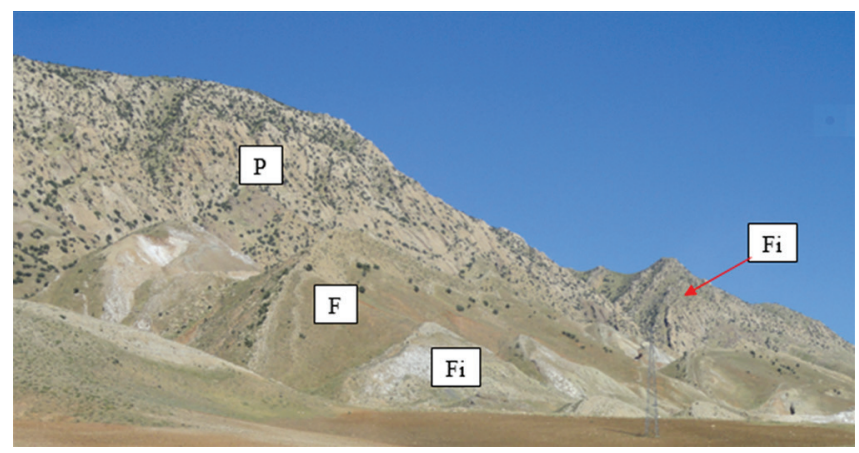

Fig. 2. Flatirons (Fi) within the Pila Spi (P) and Fatha (F) Formations. Note the continuous anticlinal ridge.

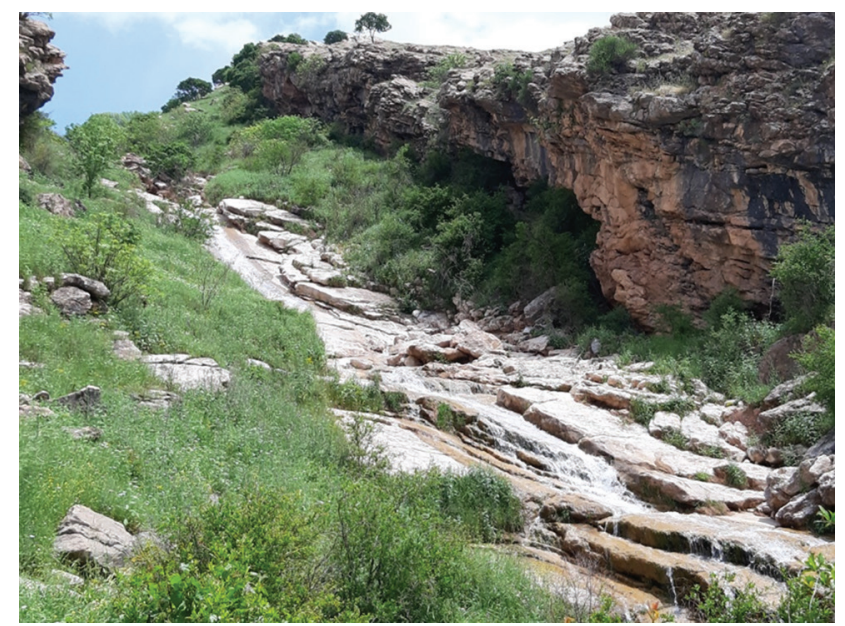

Fig. 3. The studied section. The uppermost part (the rusty colored limestone) most probably belongs to one of geological formations of the Kirkuk Group. indicate the suitability of the studied carbonates for industrial uses.

\section{A. Sample Collection}

After selecting the study area at the Haibat Sultan Mountain (Fig. 1) along Koya-Dokan road, the exposed carbonate rocks were sampled in two stages, with different sampling intervals (Table II). The sampling interval was changed with the main change in lithological characters and/ or bedding nature. Accordingly, 16 samples were collected starting from the bottom to the top (Fig. 3) of the Pila Spi Formation. The samples were described in the field; the hardness was indicated using geological hammer blows, other characters were described by naked eye.

\section{B. Sample Preparation and Analysis}

The collected samples were prepared for XRF test by the following steps:

- The samples were dried in an oven with temperature of $110^{\circ} \mathrm{C}$ for $1 \mathrm{~h}$.

- The samples were crushed using an electrical samples crusher.

- The crushed samples were ground to powder using mill machine for $5 \mathrm{~min}$.

- From each sample, $12 \mathrm{~g}$ were weighed, $0.5 \mathrm{~g}$ of steric acid and $0.2 \mathrm{~g}$ of methyl cellulose were added to homogenize the powdered sample which was pressed as a pellet.

- Finally, the samples were subjected to XRF test in the laboratories of the University of Kurdistan Hewler.

TABLE I

Specifications of Some Usages of Carbonate Rocks in Different Industries (After Al-Bassam AND Al-KhafaJi, 2011)

\begin{tabular}{|c|c|c|}
\hline \multicolumn{3}{|l|}{$\overline{\text { Limestone }}$} \\
\hline Glass industry (\%) & Cement industry (\%) & Paints $(\%)$ \\
\hline $\mathrm{CaCO}_{3}>98$ & $\mathrm{MgO}<2$ & $\mathrm{CaCO}_{3}>99.5$ \\
\hline $\mathrm{SiO}_{3}<2.0$ & $\mathrm{CaO}>45$ & $\mathrm{SiO}_{2}<1.0$ \\
\hline $\mathrm{Fe}_{2} \mathrm{O}_{3}<0.06$ & $\mathrm{SO}_{3}<1$ & $\mathrm{Al}_{2} \mathrm{O}_{3}<0.05$ \\
\hline $\mathrm{MgO}<0.05$ & $\mathrm{Cl} 0.5-1.0$ & $\mathrm{Fe}_{2} \mathrm{O}_{3}<0.05$ \\
\hline \multirow[t]{2}{*}{ L.O.I $>43$} & $\mathrm{~K}_{2} \mathrm{O}+\mathrm{Na}_{2} \mathrm{O} 0.05$ & L.O.I $>43.5$ \\
\hline & $\mathrm{Fe}_{2} \mathrm{O}_{3}<0.1$ (white cement) & \\
\hline Steel (\%) & Sugar industry (\%) & Paper industry (\%) \\
\hline $\mathrm{CaCO}_{3} 92-95$ & $\mathrm{SiO}_{2}<0.66$ & $\mathrm{CaCO}_{3}>90$ \\
\hline $\mathrm{MgCo}_{3} 1.3-1.9$ & $\mathrm{Al}_{2} \mathrm{O}_{3}<0.27$ & $\mathrm{SiO}_{2}<1.5$ \\
\hline $\mathrm{Al}_{2} \mathrm{O}_{3} 1-2$ & $\mathrm{Fe}_{2} \mathrm{O}_{3}<0.09$ & $\mathrm{MgO}<1.5$ \\
\hline $\mathrm{CaSO}_{4} 0.5-0.8$ & $\mathrm{MgO}<4.0$ & $\mathrm{SO}_{3}<1$ \\
\hline P $0.05-0.09$ & $\mathrm{CaO}>55$ & I.R $($ in $\mathrm{HCL})<4.5$ \\
\hline \multicolumn{3}{|l|}{$\mathrm{SiO}_{2} 1.5-3.5$} \\
\hline \multicolumn{3}{|l|}{ Dolomite } \\
\hline Magnesia (\%) & Metallurgy (\%) & \\
\hline \multirow[t]{6}{*}{$\overline{\mathrm{MgO}}>20$} & $\mathrm{MgO} 15-20.5$ & \\
\hline & $\mathrm{CaO} 28-35$ & \\
\hline & $\mathrm{SiO}_{2} 1.5-3.5$ & \\
\hline & $\mathrm{Al}_{2} \mathrm{O}_{3} 1-3$ & \\
\hline & $\mathrm{SO}_{3} 0.5-1.5$ & \\
\hline & Moisture 2-10 & \\
\hline
\end{tabular}


TABLE II

Field Description of the Collected Samples from the Study Area

\begin{tabular}{|c|c|c|c|c|c|}
\hline \multirow[t]{2}{*}{$\overline{\text { Sample no. }}$} & \multirow[t]{2}{*}{ Color } & \multirow[t]{2}{*}{ Hardness } & \multicolumn{2}{|c|}{ Thickness (m) } & \multirow[t]{2}{*}{ Reaction with $\mathrm{HCl}$ acid } \\
\hline & & & Sample interval & Individual bed & \\
\hline 1. & Grayish-white & Hard & 1 & $0.3-0.5$ & Reactive \\
\hline 2. & Grayish-white & Hard & 2 & $0.3-0.5$ & Reactive \\
\hline 3. & Grayish-white & Hard & 2 & $0.3-0.5$ & Reactive \\
\hline 4. & Yellowish-white & Hard & 1 & $0.2-0.4$ & Reactive \\
\hline 5. & Grayish-white & Hard & 2 & $0.3-0.5$ & Highly reactive \\
\hline 8. & Grayish-white & Hard & 2 & $0.3-0.5$ & Highly reactive \\
\hline 9. & Grayish-white & Hard & 2 & $0.3-0.5$ & Highly reactive \\
\hline 10. & Grayish-white & Hard & 2 & $0.3-0.5$ & Highly reactive \\
\hline 11. & Light brown & Very hard & 4 & $0.5-1.5$ & Highly reactive \\
\hline 12. & Light brown & Very hard & 5 & $0.5-1.5$ & Highly reactive \\
\hline 13. & Light brown & Very hard & 5 & $1.0-1.5$ & Highly reactive \\
\hline
\end{tabular}

TABLE III

Concentration of Oxides in the Collected Samples (Indicated by XRF Test)

\begin{tabular}{lccccccc}
\hline \hline $\begin{array}{l}\text { Sample } \\
\text { no. }\end{array}$ & $\mathrm{CaO}(\%) \mathrm{MgO}(\%)$ & $\mathrm{SiO}_{2}(\%)$ & $\mathrm{Fe}_{2} \mathrm{O}_{3}(\%)$ & $\mathrm{Al}_{2} \mathrm{O}_{3}(\%)$ & $\mathrm{S}(\%)$ & L.O.I. $(\%)$ \\
\hline 1. & 50.10 & N.D. & 3.03 & 0.18 & N.D. & 0.15 & 46.60 \\
2. & 50.23 & N.D. & 2.93 & 0.16 & N.D. & 0.12 & 46.55 \\
3. & 45.5 & 2.90 & 3.94 & 0.38 & 0.53 & 0.13 & 56.60 \\
4. & 51.11 & 1.55 & 3.60 & 0.15 & N.D. & 0.12 & 44.77 \\
5. & 46.50 & 2.00 & 2.46 & 0.13 & N.D. & 0.13 & 58.70 \\
6. & 50.20 & 1.01 & 3.61 & 0.12 & N.D. & 0.12 & 44.78 \\
7. & 45.8 & 2.90 & 3.30 & 0.15 & N.D. & 0.13 & 57.70 \\
8. & 46.22 & 1.83 & 3.12 & 0.11 & 0.24 & 0.11 & 48.30 \\
9. & 45.00 & 2.03 & 3.17 & 0.15 & 0.21 & 0.15 & 49.30 \\
10. & 51.25 & N.D. & 3.64 & 0.14 & N.D. & 0.15 & 44.80 \\
11. & 51.20 & N.D. & 2.64 & 0.16 & N.D. & 0.17 & 45.80 \\
12. & 51.73 & N.D. & 1.78 & 0.12 & N.D. & 0.13 & 46.17 \\
13. & 49.30 & 1.84 & 3.22 & 0.18 & N.D. & 0.14 & 46.30 \\
14. & 51.20 & 1.23 & 1.76 & 0.14 & N.D. & 0.15 & 48.20 \\
15. & 51.21 & 1.45 & 1.73 & 0.11 & N.D. & 0.13 & 47.20 \\
16. & 51.70 & N.D. & 1.80 & 0.13 & N.D. & 0.14 & 46.20 \\
\hline \hline
\end{tabular}

N.D.: Not detected

\section{RESULTS}

The acquired results from running XRF test on the collected and prepared 16 samples are presented in Table III. The determined percentage of the main oxides which can be used in the industrial assessment of the studied carbonate rocks (Table I) was changed to the weighted averages for each oxide at each sample, the results are presented in Table IV. The weighted average is calculated according to the following equation:

Weighted average $=$ Concentration of each oxide $(\%) \times$ thickness of each sample (m)

Total weighted average $=$ Sum of all weighted averages (of each oxide)/Total thickness of the samples (m)

The $\mathrm{Na}_{2} \mathrm{O}, \mathrm{K}_{2} \mathrm{O}$, and $\mathrm{MnO}$ were also analyzed but all of them were below the detection limits.

\section{DISCUSSION}

In Iraqi Kurdistan Region, the carbonate rocks are limestone and dolomite. The main use of the limestone beds is only in cement production although enormous amounts of limestone are widely exposed in the region (Sissakian and Saeed, 2012). However, it is very locally used as an aggregate but without any scientific studies as it is the case in the dolomite beds everywhere in the region.

The dolomite, however, is rarely used in its raw state, but it is considered as a useful source in making steel as a refractory lining material, as well as in manufacturing paper, leather, glass, and agricultural dolomite (McGregor, 1963). For glass production, a little amount of dolomitic lime is used to produce durable glass. Dolomite is also used to neutralize soil and high calcium limestone, particularly the one which is 84 parts magnesium carbonate and 100 parts calcium carbonate, having equal powers to neutralize soil (McGregor, 1963). Dolomite can be used as a basic refractory material, especially in the machine tools and steel making industry. Dolomite refractories intensively participate in the steel industry where it is used in open hearth, basic oxygen converters, and other steel refining systems (Moorkah and Abolarin, 2005). However, none of the mentioned industries exist in Iraqi Kurdistan Region although dolomite can be found in all parts of the region with huge thicknesses and amounts (Sissakian and Saeed, 2012).

\section{A. Industrial Assessments}

The acquired weighted averages of the analyzed oxides (Table III) were compared with some industrial standards to indicate the suitability of the collected samples which represent the rocks of the Pila Spi Formation east of Koya town (Table V). Accordingly, the acquired results from the XRF test match the specifications of the following industries: 
- Cement industry: The weighted averages of the oxides in the collected rock samples match those required for the cement production (Table IV). It is worth to mention that there are

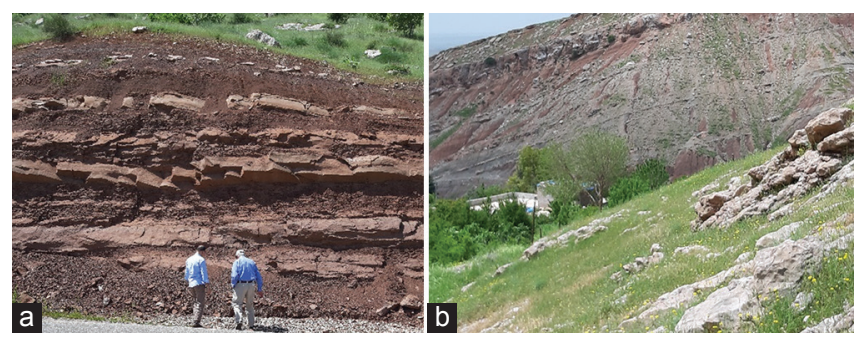

Fig. 4. Claystone beds, (a) (left) Gercus Formation, (b) (Right) Fatha Formation.

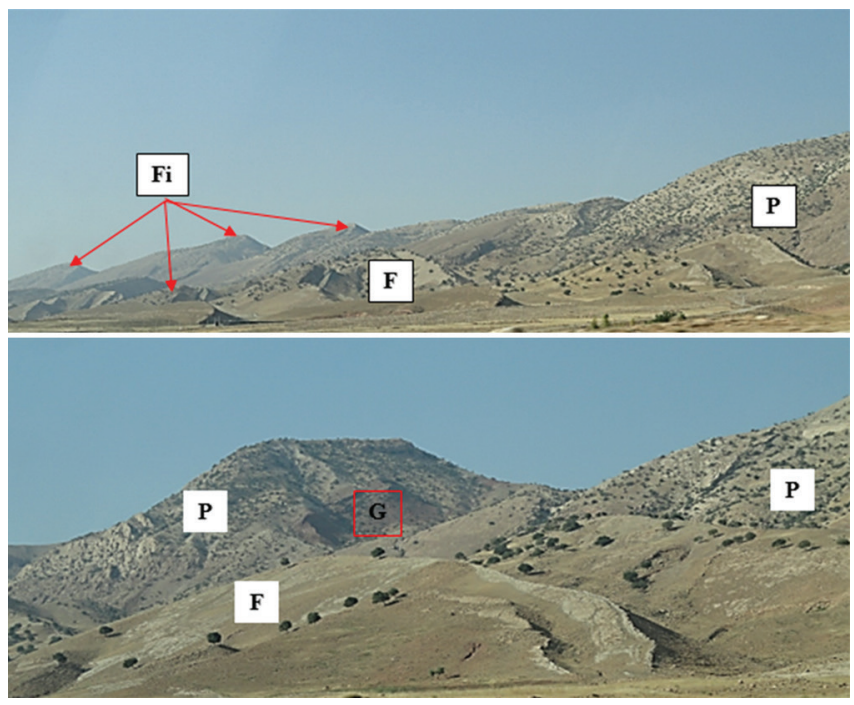

Fig. 5. The Pila Spi Formation (P) in the studied area. Note the absence of overburden, presence of thick claystone beds in the Gercus (G) and Fatha (F) Formations. huge thicknesses of claystone (the second raw material in cement production) in the study area. These are present above the carbonates of the Pila Spi Formation within the Gereus Formation and bellow the earbonates present in the Fatha Formation (Fig. 4).

- Paper industry: The weighted averages of the oxides in the collected rock samples match (almost) those required for the paper industry. The infrared radiation (I.R.) concentration is not indicated, but the concentration of the $\mathrm{SiO}_{2}$ is $2.52 \%$ (Table IV), then the I.R. $\%$ is $<4.5 \%$, which means that it matches the required specification.

- Paint industry: The weighted averages of the oxides in the collected rock samples match (almost) those required for the paint industry although the $\mathrm{SiO}_{2}$ concentration is $2.52 \%$ which is slightly higher than the specified standard (1.0\%) (Table IV). This slightly higher concentration will affect on the coarseness and corrosiveness of the paint. However, outdoor paints need such character; accordingly, the exposed rocks can be used for paint industry.

- Sugar and glass industries: The weighted averages of the oxides in the collected rock samples do not match the required specifications (Table IV). However, for each industry, a special treatment may solve the non-matching of the required specifications. For example, in glass industry, adding a pure limestone with high $\mathrm{CaO}$ content will solve the problem of non-marching the required specifications. For sugar industry, again adding a pure limestone with high $\mathrm{CaO}$ content will solve the problem of non-matching the required specifications. However, the higher $\mathrm{Fe}_{2} \mathrm{O}_{3}$ will give brownish color for the produced sugar; however, the high $\mathrm{SiO}_{2}$ will remain an obstacle for sugar productions. The high $\mathrm{SiO}_{2}$ in the analyzed samples is a problem for all possible industries (Table IV). To get rid of the high $\mathrm{SiO}_{2}$, special treatment should be performed which is not easy and cause a lot of problems due to its high corrosiveness character.

TABLE IV

Concentrations and Weighted Averages of the Main Oxides in the eight Analyzed Samples

\begin{tabular}{|c|c|c|c|c|c|c|c|c|c|c|c|c|c|c|c|}
\hline \multirow[t]{2}{*}{ Sample no. } & \multirow[t]{2}{*}{ Thick. (m) } & \multicolumn{2}{|c|}{$\mathrm{CaO}(\%)$} & \multicolumn{2}{|c|}{$\mathrm{MgO}(\%)$} & \multicolumn{2}{|c|}{$\mathrm{SiO}_{2}(\%)$} & \multicolumn{2}{|c|}{$\mathrm{Fe}_{2} \mathrm{O}_{3}(\%)$} & \multicolumn{2}{|c|}{$\mathrm{Al}_{2} \mathrm{O}_{3}(\%)$} & \multicolumn{2}{|c|}{ S (\%) } & \multicolumn{2}{|c|}{ L.O.I. (\%) } \\
\hline & & Con. & W.A. & Con. & W.A. & Con. & W.A. & Con. & W.A. & Con. & W.A. & Con. & W.A. & Con. & W.A. \\
\hline 1. & 2 & 50.10 & 100.20 & N.D. & N.D. & 3.03 & 6.06 & 0.18 & 0.36 & N.D. & N.D. & 0.15 & 0.30 & 46.60 & 93.20 \\
\hline 2. & 2 & 50.23 & 100.46 & N.D. & N.D. & 2.93 & 5.86 & 0.16 & 0.32 & N.D. & N.D. & 0.12 & 0.24 & 46.55 & 93.10 \\
\hline 3. & 2 & 45.5 & 91.00 & 2.90 & 5.80 & 3.94 & 7.88 & 0.38 & 0.76 & 0.53 & 1.06 & 0.13 & 0.26 & 56.60 & 113.20 \\
\hline 4. & 1 & 51.11 & 51.11 & 1.55 & 1.55 & 3.60 & 3.60 & 0.15 & 0.15 & N.D. & N.D. & 0.12 & 0.12 & 44.77 & 44.77 \\
\hline 5. & 2 & 46.50 & 93.00 & 2.00 & 4.00 & 2.46 & 4.92 & 0.13 & 0.26 & N.D. & N.D. & 0.13 & 0.26 & 48.70 & 97.40 \\
\hline 6. & 2 & 50.20 & 100.40 & 1.01 & 2.02 & 3.61 & 7.22 & 0.12 & 0.24 & N.D. & N.D. & 0.12 & 0.24 & 44.78 & 89.56 \\
\hline 7. & 2 & 45.8 & 91.60 & 2.90 & 5.80 & 3.30 & 6.60 & 0.15 & 0.30 & N.D. & N.D. & 0.13 & 0.26 & 47.70 & 95.40 \\
\hline 8. & 2 & 46.22 & 92.44 & 1.83 & 3.66 & 3.12 & 6.24 & 0.11 & 0.22 & 0.24 & 0.48 & 0.11 & 0.22 & 48.30 & 96.60 \\
\hline 9. & 2 & 45.00 & 90.00 & 2.03 & 4.06 & 3.17 & 6.34 & 0.15 & 0.30 & 0.21 & 0.42 & 0.15 & 0.30 & 49.30 & 98.60 \\
\hline 10. & 2 & 51.25 & 102.50 & N.D. & N.D. & 3.64 & 7.28 & 0.14 & 0.28 & N.D. & N.D. & 0.15 & 0.30 & 44.80 & 89.60 \\
\hline 11. & 4 & 51.20 & 204.80 & N.D. & N.D. & 2.64 & 10.56 & 0.16 & 0.70 & N.D. & N.D. & 0.17 & 0.56 & 45.80 & 224.00 \\
\hline 12. & 5 & 51.73 & 258.65 & N.D. & N.D. & 1.78 & 7.40 & 0.12 & 0.60 & N.D. & N.D. & 0.13 & 0.65 & 46.17 & 230.85 \\
\hline 13. & 5 & 49.30 & 246.50 & 1.84 & 9.20 & 3.22 & 16.10 & 0.18 & 0.90 & N.D. & N.D. & 0.14 & 0.70 & 46.30 & 231.50 \\
\hline 14. & 5 & 51.20 & 256.00 & 1.23 & 6.15 & 1.76 & 8.80 & 0.14 & 0.70 & N.D. & N.D. & 0.15 & 0.75 & 48.20 & 241.00 \\
\hline 15. & 7 & 51.21 & 358.47 & 1.45 & 10.15 & 1.73 & 12.11 & 0.11 & 0.77 & N.D. & N.D. & 0.13 & 0.91 & 47.20 & 330.40 \\
\hline 16. & 5 & 51.70 & 258.50 & N.D. & N.D. & 1.80 & 9.00 & 0.13 & 0.65 & N.D. & N.D. & 0.14 & 0.70 & 46.20 & 231.00 \\
\hline Total & 50 & & 2495.63 & & 52.39 & & 125.97 & & 7.51 & & 1.96 & & 6.77 & & 2406.18 \\
\hline Average & & & 49.91 & & 1.05 & & 2.52 & & 0.15 & & 0.04 & & 0.14 & & 48.12 \\
\hline
\end{tabular}

N.D.: Not detected 
TABLE V

Specifications of Some Industries as Compared with the Results of the Current Study

\begin{tabular}{|c|c|c|c|c|c|c|c|c|c|c|c|}
\hline \multicolumn{12}{|c|}{ Specifications of industries (\%) } \\
\hline \multicolumn{2}{|c|}{ Cement industry } & Current study & \multicolumn{2}{|c|}{ Paint industry } & Current study & \multicolumn{2}{|c|}{ Steel industry } & Current study & \multicolumn{2}{|c|}{ Sugar industry } & Current study \\
\hline $\mathrm{CaO}$ & $>45.00$ & 49.91 & $\mathrm{CaCO}_{3}$ & $>99.5$ & 96.53 & $\mathrm{CaCO}_{3}$ & $92-95$ & 98.03 & $\mathrm{MgO}$ & $<4.00$ & 1.05 \\
\hline $\mathrm{Fe}_{2} \mathrm{O}_{3}$ & $<0.10$ & 0.15 & $\mathrm{Al}_{2} \mathrm{O}_{3}$ & $<0.05$ & 0.05 & $\mathrm{Al}_{2} \mathrm{O}_{3}$ & $1-2$ & 0.04 & $\mathrm{Al}_{2} \mathrm{O}_{3}$ & $<0.27$ & 0.04 \\
\hline $\mathrm{SO}_{3}$ & \multicolumn{2}{|c|}{$<1.00$} & $\mathrm{Fe}_{2} \mathrm{O}_{3}$ & $<0.05$ & 0.15 & $\mathrm{CaSO}_{4}$ & $0.5-0.8$ & & $\mathrm{Fe}_{2} \mathrm{O}_{3}$ & $<0.09$ & 0.15 \\
\hline \multicolumn{2}{|c|}{ Glass industry } & Current study & \multicolumn{2}{|c|}{ Metallurgy } & Current study & \multicolumn{2}{|c|}{ Magnesia } & Current study & \multicolumn{2}{|c|}{ Paper industry } & Current study \\
\hline $\mathrm{CaCO}_{3}$ & $>98.00$ & 98.03 & $\mathrm{CaCO}_{3}$ & $92-95$ & 98.03 & $\mathrm{MgO}$ & $>20$ & 1.05 & $\mathrm{CaCO}_{3}$ & $>90$ & 98.03 \\
\hline $\mathrm{SiO}_{2}$ & $<2.00$ & 2.52 & $\mathrm{MgO}$ & $1.3-1.9$ & 1.05 & & & & $\mathrm{MgO}$ & $<1.5$ & 1.05 \\
\hline MgO & $<0.05$ & 1.05 & $\mathrm{Al}_{2} \mathrm{O}_{3}$ & $1-3$ & 0.04 & & & & $\mathrm{SiO} 2$ & $<1.5$ & 2.52 \\
\hline
\end{tabular}

Legend: $\square$ Out of the standard, $\square$ Fit with the standards, $\ldots$ Not analyzed or detected, $\square$ Near to the standard, $\square$ Suitable, $\square$ Suitable with treatment, $\square$ Not suitable,

Fairly suitable, IR:Infrared radiation

- Metallurgy and magnesia production: The weighted averages of the oxides in the collected rock samples (Table IV) are very far from the requested specifications. Therefore, the studied rock succession of the Pila Spi Formation cannot be used in metallurgy and magnesia production.

\section{B. Quarrying Conditions}

During choosing the studied section, the quarrying conditions (Fig. 5) were considered including dip amount, quarrying faces, transportability, thickness, overburden, inner burden, and availability of other raw materials, especially for cement production. Although the dip amount is about $30^{\circ}$, still considerable thickness can be utilized by quarrying without a need for below surface level quarrying. The large flatirons (Figs. 1,2 and 5) give excellent quarrying faces from three directions. The main Erbil-Sulaymaniyah road passes $2 \mathrm{~km}$ south of the studied section. Moreover, the planned (permanently abandoned) tunnel is few hundred meters west of the studied section. The sampled thickness is $50 \mathrm{~m}$; however, the total thickness may reach $65 \mathrm{~m}$. Almost no overburden exists on the limestone beds of the Pila Spi Formation. However, downslope the Fatha Formation is exposed which consists of an alternation of claystone, limestone, and gypsum. All three main components are required in cement production as raw material and/or additive. All the sampled beds showed suitable and almost uniform results in their chemical composition (Table II) which means that there is no inner burden. The well-bedded nature of the limestone beds of the Pila Spi Formation facilitates the quarrying of the rocks by least amount of explosives.

\section{CONCLuSIONS}

The exposed rocks in the Pila Spi Formation along the southwestern limb of Khalikan anticline east of Koya town and along Haibat Sultan Mountain can be used for cement industry. The presence of huge amounts of claystone in both Gercus and Fatha Formations (underlying and overlying the Pila Spi Formation, respectively) encourages construction of a cement plant. All quarrying conditions are suitable besides the presence of huge reserves. Moreover, the limestone beds can be used for paper and paint industries with slight treatments. They can also be used for glass and sugar industries, but a lot of special treatments are needed. However, the studied carbonates cannot be used in magnesia production and other metallurgical uses.

\section{ACKNOWLEDGMENT}

The authors would like to express their sincere thanks to the authorities in both University of Kurdistan Hewler and University of Koya for their support to the authors during the performance of the research work which led to the current article. The efforts of Mr. Hassan Omer (University of Kurdistan Hewler) for running the XRF analyses and supplying the chemical composition of the collected rock samples are highly appreciated by the authors. The authors extend their thanks to the esteemed reviewers for their fruitful comments.

\section{REFERENCES}

Al-Bassam, K. and Al-Khafaj, A.A., 2011. Work Procedures of Iraq Geological Survey, Part 13: Mineral Exploration. Iraq Geological Survey Library Report, No. 2133.

Al-Murib, S., 1980. Report on Prospecting Works on Limestone for Cement Industry in Southern Qara Chouq Mountain. Iraq Geological Survey Library Report, No. 1057.

Al-Rufaie, A. and Muhamad, S., 1976. Report on the Geological Prospecting of Limestone Deposit Suitable for Cement Purpose at Qara Choug Mountain, Khoshao Locality, Arbil. Iraq Geological Survey Library Report, No. 1786. 
Al-Rufaie, I., 1976. Investigation of Limestone Suitable for Cement Industry in Qara Chauq Mountain, Khoshao Area. Iraq Geological Survey Library Report, No. 1379.

Etabi, W. and Ahmed, S., 1979. Final Report on Prospecting Exploration of Tasluja Limestone Deposit Suitable for Portland Cement. Iraq Geological Survey Library Report, No. 961.

Fouad, S.F., 2012. Tectonic Map of Iraq, Scale 1: 1000000. $3^{\text {rd }}$ ed. Iraq Geological Survey Publications, Baghdad, Iraq.

Hafidh, S.Q. and Hassan, A.A., 2008. Exploration of Limestone Suitable for Cement Industry in Categories C1 and B at Sartak South of Derbendikhan. Iraq Geological Survey Library Report, No. 3125.

Hafidh, S.Q. and Khlaif, H.O., 2007. Mineral Exploration and Reserve Estimation in Category Cl of the Carbonate Rocks Suitable for Cement Manufacturing at Tasluja, Sulaimaniyah on the Behalf of Sarchinar Cement Plant. Iraq Geological Survey Library Report No. 3038.

Hafidh, S.Q. Ruhman, A., Al-Abaas, F.A., Rasheed, A.Y. and Qanbar, A.S., 2008a. Preliminary Geological Studies of Limestone Suitable for Cement Industry in Sartak and Kani Kel Vicinity Southeast of Darbandi Khan Southeast of Sulaimaniyah Governorate. Iraq Geological Survey Library Report, No. 3125.

Hafidh, S.Q., Al-Jiburi, B.S. and Basheer, W.P., 2011. Detailed Geological Survey at Scale of 1:5000 in Southern Qara Chauq Mountain, Block/A, for Investigation of Limestone Suitable for Cement Industry in Behalf of Kar Company. Iraq Geological Survey Library Report, No. 3400.

Hafidh, S.Q., Salih, H.A. and Abbas, A.K.A., 2008c. Preliminary Geological Studies on Limestone Suitable for Cement Industry, West of Suliamaniyah on the Behalf of Washa Co. Iraq Geological Survey Library Report, No. 3127.

Hafidh, S.Q., Salih, H.A. and Mahmoud, A.A., 2008b. Preliminary Studies on Limestone Suitable for Cement Industry. Agh Jallar Vicinity on the Behalf of Mawlawi Co. Iraq Geological Survey Library Report, No. 3128.
Jaber, F.S. and Al-Ubaidi, H., 1973. Kani China Recrystalline Limestone. Iraq Geological Survey Library Report, No. 524.

Mansour, J. and Petranek, J., 1980. Major Occurrences and Deposits of Limestone in Iraq. Iraq Geological Survey Library Report, No. 1073.

Mansour, J., 1976. Reconnaissance of the Kirkuk, Erbil, Sulaimaniyah Area on Search for Raw Materials in Connection with Proposed Cement Works. Iraq Geological Survey Library Report, No. 768.

Mansour, J., 1977. Preliminary Examination of the Raw Materials for Al-Tamim Cement Project. Iraq Geological Survey Library Report No. 840.

McGregor, D., 1963. High-Calcium Limestone and Dolomite in Indiana. $27^{\text {th }} \mathrm{ed}$. Indiana Department of Conservation, State of Indiana, p.1-12.

Moorkah, H. and Abolarin, M., 2005. Investigation of the properties of locally available dolomite for refractory applications. Nigerian Journal of Technology, 24(1), p.79-81.

Sissakian, V.K. and Al-Jiburi, B.M., 2014. Stratigraphy of the High Folded Zone. Iraqi Bulletin of Geology and Mining, 6, p.73-16.

Sissakian, V.K. and Fouad, S.F., 2012. Geological Map of Iraq, Scale 1: 1000000. $4^{\text {th }}$ ed. Iraq Geological Survey Publications, Baghdad, Iraq.

Sissakian, V.K. and Fouad, S.F., 2014. Geological Map of Erbil and Mahabad Quadrangles, Scale 1: 250000. $2^{\text {nd }}$ ed. Iraq Geological Survey Publications, Baghdad, Iraq.

Sissakian, V.K. and Saeed, Z.B., 2012. Lithological map of Iraq compiled using GIS Techniques. Iraqi Bulletin of Geology and Mining, 8(3), p.1-13.

Sissakian, V.K., Hamoudi, D.A., Omer, H.O. and Niazi, S.A., 2019. Assessment of the carbonate rocks of the Pila Spi formation for cement industry, in Permam mountain, Erbil, Iraqi Kurdistan Region. UKH Journal of Science and Engineering, 3(1), pp.1-9. 